\title{
Iron ooid beds of the Carolinefjellet Formation, Spitsbergen, Norway
}

\author{
Jeremy Mutrux, Harmon Maher, Robert Shuster \& Troy Hays \\ Department of Geography and Geology, University of Nebraska at Omaha, Omaha, NE 68182-0199, USA
}

\begin{abstract}
Keywords
Carolinefjellet Formation; chamosite; Cretaceous; iron ooid; Spitsbergen; storm.

\section{Correspondence}

Harmon Maher, Dept. of Geography and Geology, University of Nebraska at Omaha, Omaha, NE 68182-0199, USA. E-mail:

harmon_maher@mail.unomaha.edu
\end{abstract}

doi:10.1111/j.1751-8369.2007.00039.x

\begin{abstract}
Iron ooid beds are unusual deposits that have been linked to greenhouse conditions and the transgressive flooding of shallow shelves, and which were globally prevalent during certain periods. Within the marine, Aptian-Albian, Carolinefjellet Formation of Spitsbergen, chamosite ooids have been found within distinctive sandstone beds at six localities, and at a consistent stratigraphic position within the basal Dalkjegla Member. Distinctive characteristics include the iron ooids themselves, a coarser grain size, intercalation with silty siderites, grading, cross-beds indicating offshore or longshore transport, and a lack of burrowing. The enclosing sands display planar and hummocky crossstratification and abundant oscillation ripple marks, and are interpreted as lagoon-attached bar complexes. The stratigraphic position and traits of the iron ooid sands are consistent with seaward storm transport and preservation within interbar swales. Ooids vary in shape considerably, and display evidence for multiple growth events. Nuclei of quartz, opaques, carbonate clasts and laminated crusts are typically encircled by finer grained tangential chamosite and opaque laminae, sometimes with outer overgrowths of calcite and/or radial chamosite. The Dalkjegla Member is the marine portion of a large-scale transgressive tract, attached to underlying fluvio-estuarine Helvetiafjellet Formation strata. A lagoonal environment associated with the basal shales of the Dalkjegla Member represents a logical setting, where riverine iron concentration and iron silicate growth could occur. The Spitsbergen iron ooid beds extend the known occurrence of Cretaceous examples, representing a less common High-Latitude example, and one not directly associated with a transgressive flooding surface.
\end{abstract}

Abundant literature discusses the palaeoenvironmental significance of and formation mechanisms for iron ooids (e.g., Young \& Taylor 1989; Taylor et al. 2002). Iron ooids are of particular interest because of their relative stratigraphic rarity, their historical distribution and their disputed conditions of formation. They have been linked to greenhouse periods and global oceanic anoxia (e.g., Young \& Taylor 1989; Garzanti 1993), to sequence boundaries (Taylor et al. 2002) and to episodes of increased mafic volcanism (Sturesson 2003). Questions arise about how to interpret their diverse mineralogy and textures, with attention focused on which iron ooid mineral phases and textures are primary, which are related to shallow burial (and prone to reworking) and which are the result of later replacement (e.g. Taylor et al. 2002; Collin et al. 2005). Growth mechanisms are debated
(Flügel 2004), as are the mechanisms of iron concentration (e.g., Heikoop et al. 1996), and the role that microbial processes may play (Konhauser et al. 2002).

Herein, we describe the stratigraphic position, and sedimentologic and petrologic characteristics, of a previously undescribed iron ooid sandstone horizon found in the basal Dalkjegla Member of the Cretaceous age Carolinefjellet Formation at five locations in central Spitsbergen: east Skolten, west Skolten, Foxdalen, Midterhuken and Festningen (Fig. 1). The iron ooid horizon was also found at Halwylfjellet, west of Skolten, but this site is presently undescribed because there was insufficient time to make detailed field observations. We then develop a model for the environments of ooid growth and preservation for the Carolinefjellet Formation beds based on the observed traits and on the literature 
Fig. 1 Location of study areas. Abbreviations: F, Festningen; FD, Foxdalen; H, Halwylfjellet; M, Midterhuken; SE, east Skolten; SW, west Skolten. The grey shading indicates the outcrop area of the Helvetiafjellet and Carolinefjellet formations, which flank the interior Tertiary foreland basin. Lower right inset map shows the position of Spitsbergen in the North Atlantic.

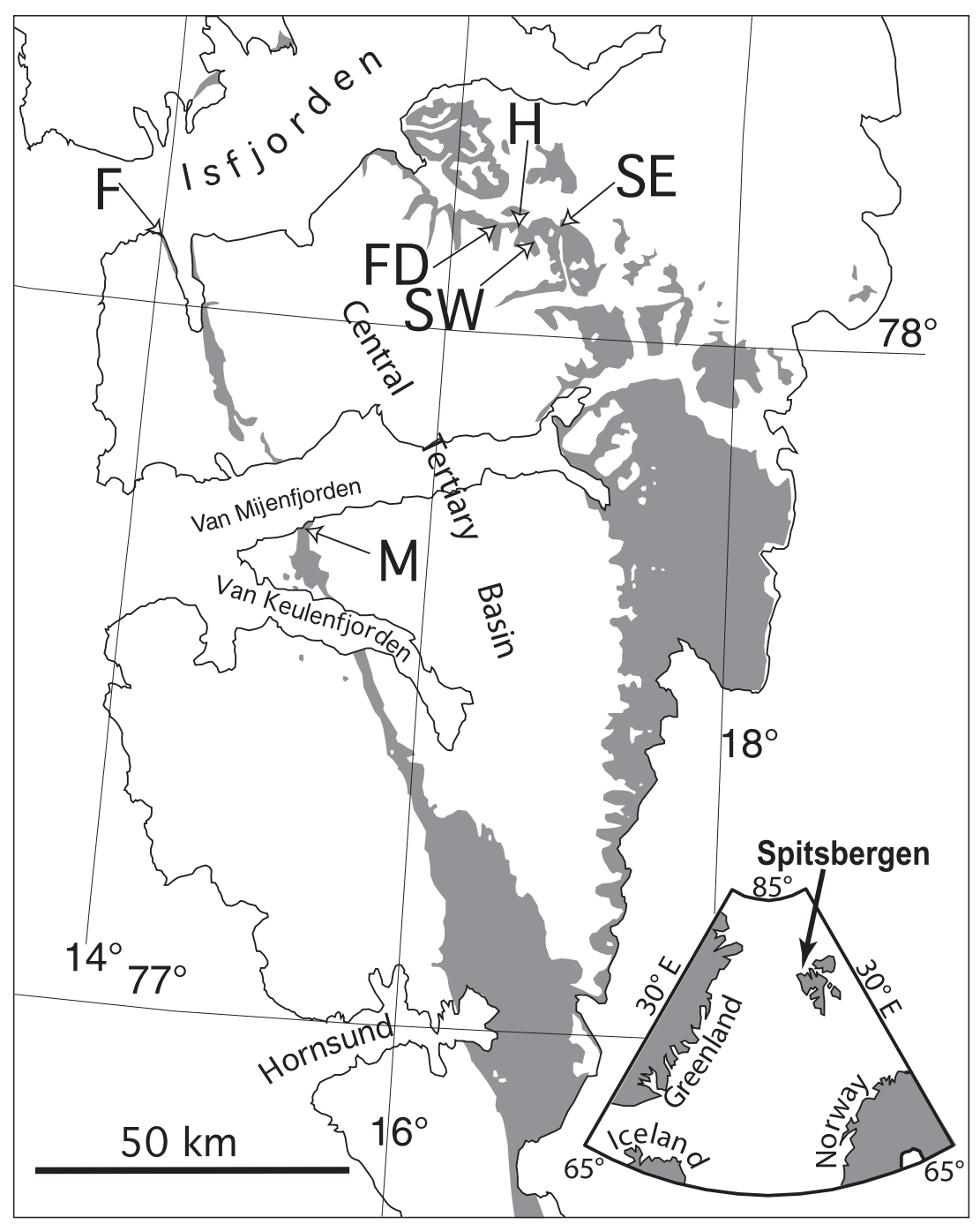

that constrains iron ooid formation conditions. Finally, we briefly consider the Dalkjegla Member occurrence in the context of global patterns of iron ooid occurrence and current thoughts on iron ooid genesis.

\section{Stratigraphic and palaeogeographic context of the iron ooid horizons}

The Carolinefjellet Formation is an Aptian-Albian marine succession the basal unit of which, the Dalkjegla Member, transgressively overlies the fluvio-estuarine sand-dominated Helvetiafjellet Formation. The Barremian Helvetiafjellet Formation is interpreted as a firstorder, transgressive fluvial and coastal sand system, which overlies an erosional base and sequence boundary in western and central Spitsbergen (Gjelberg \& Steel 1995). Underlying are organic rich marine shales of the Hauterivian age Rurikfjellet Formation. This sequence boundary between the Rurikfjellet and Helvetiafjellet formations has been associated with the onset of regional magmatism, as part of the High Arctic Large Igneous Province (HALIP; Tarduno 1998; Maher 2001).

The iron ooid sandstone horizon occurs consistently 22-30 $\mathrm{m}$ above the base of the Carolinefjellet Formation, in the lowermost part known as the Dalkjegla Member (Figs. 2-6). This member is characterized by "fine- to medium-grained, flaggy, thin-bedded greenish grey sandstones with intercalated grey siltstones and shales" (Dallmann 1999: 205). An abundance of oscillation ripple marks, planar lamination in the sandstones, hummocky cross-stratification and conglomeratic storm beds indicates significant storm/wave reworking for much of the Dalkjegla Member (Nøttvedt \& Kriesa 1987; Maher et al. 2004; Maher \& Shuster 2007), features consistent with a lower shoreface setting (e.g., McCubbin 1982). 


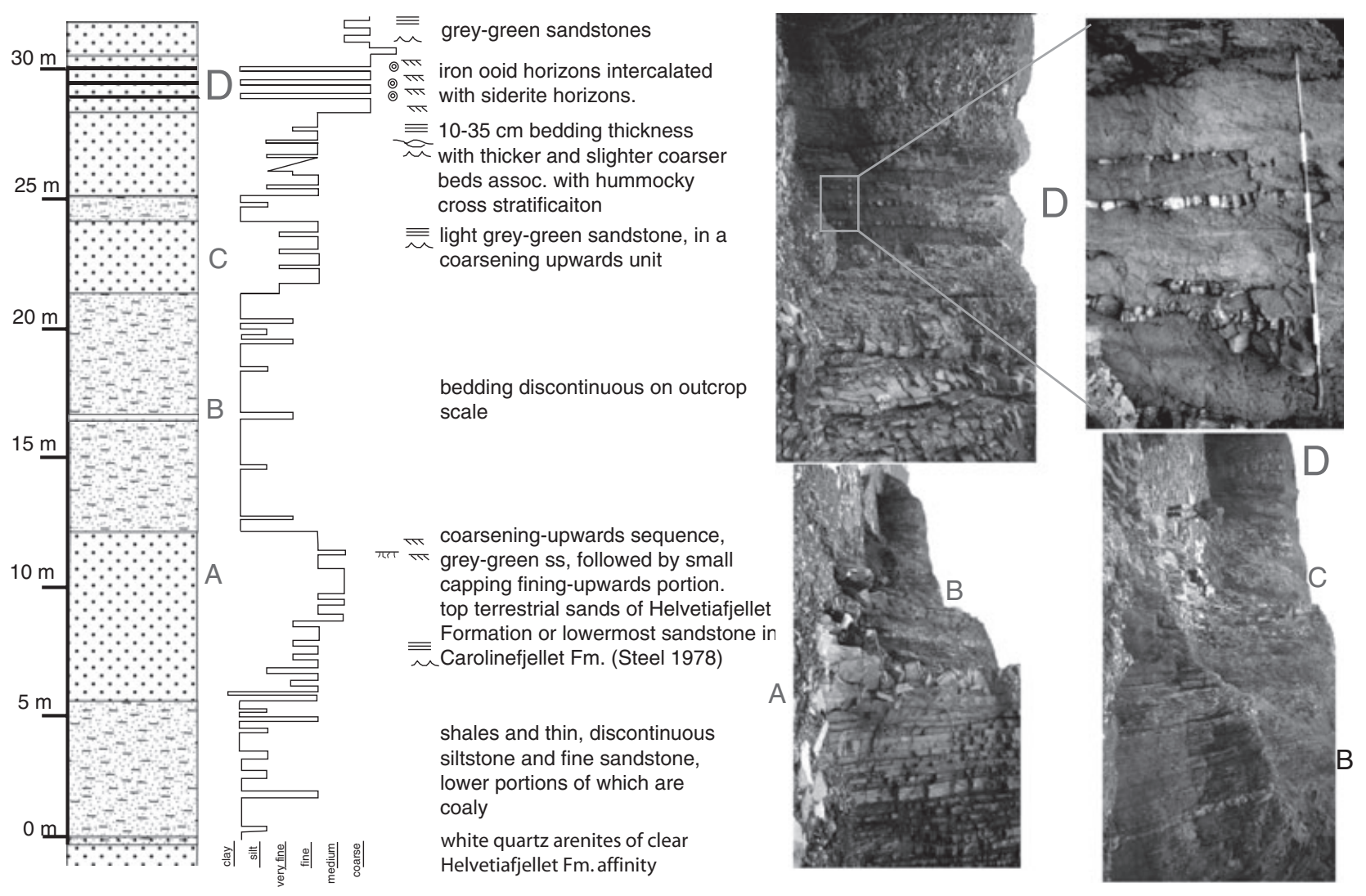

LEGEND

$\longleftarrow$ transport direction
oscillation ripple

Fig. 2 Lithologic logs showing the position of iron ooid beds, along with field photographs from the Festningen site. Photographs are oriented so that the subvertical strata are younger towards the page top (looking south). Letters on the photographs and stratigraphic column represent corresponding positions. The upper left photograph shows the recessive iron ooid horizons flanked by the more typical laminar sands of the Carolinefjellet Formation. The upper right photograph shows details of the iron ooid horizons. The lighter and more fractured layers are micrites that drape current-ripple forms. Sediment transport was to the south-west, up-dip in its present upright position.

In thinner-bedded and finer grained portions of the Dalkjegla Member a tidal-flat signature exists in some areas (Birkenmajer 1966), as evidenced by flaser bedding and a bimodal palaeocurrent pattern. Palaeocurrent pat- terns and facies distribution are consistent with an interpretation of migrating sand bodies in a wavedominated, low-relief, barrier-sand environment with strong north-east to south-west shoreline-parallel trans- 


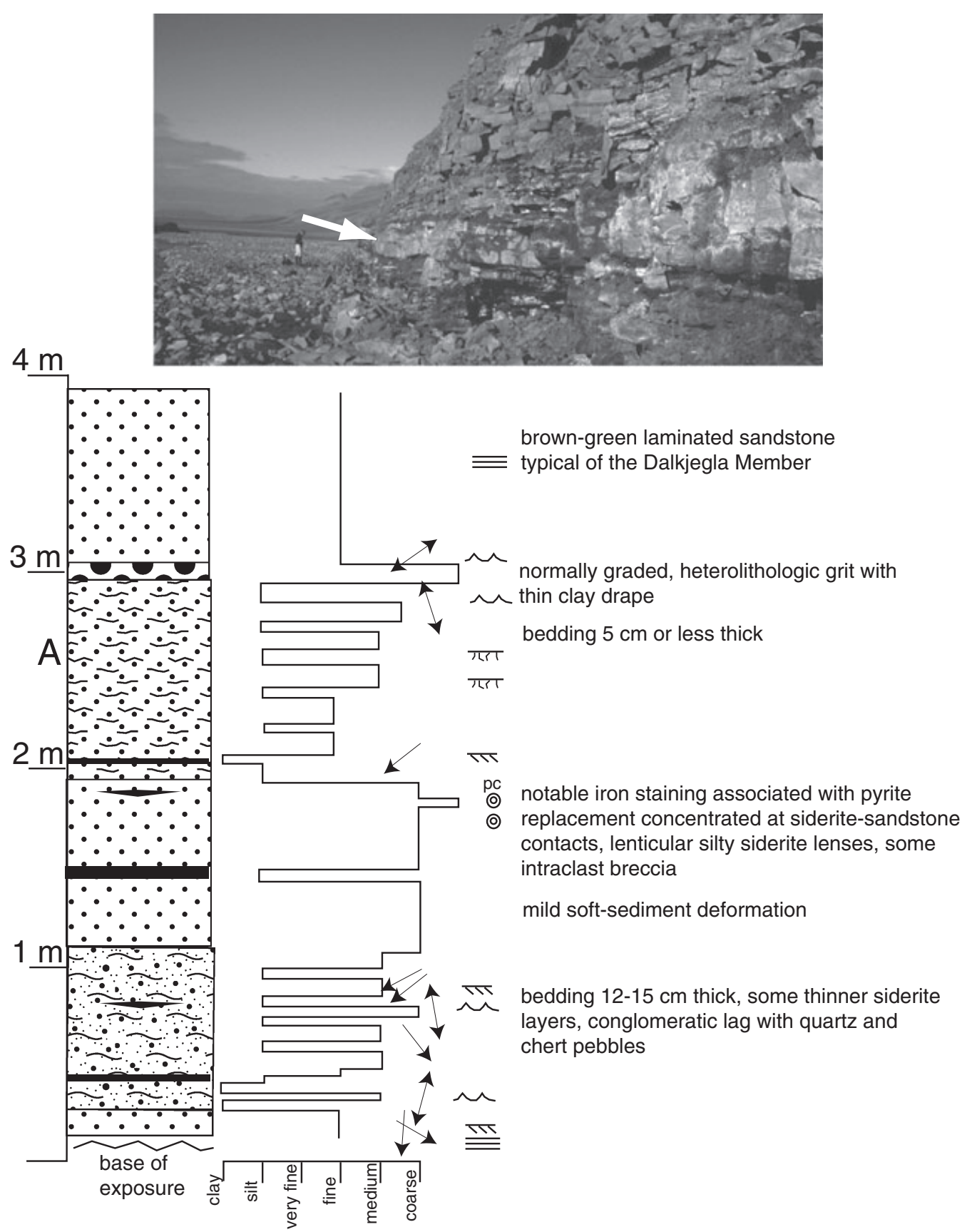

Fig. 3 Lithologic log and photograph showing the position of the Foxdalen iron ooid beds. The outcrop is on the east side of Foxdalen near the valley mouth. The arrow designates the position of the iron ooid layer. Symbols are as indicated in the legend of Fig. 2. Note that the person has been included for scale in the photograph.

port (Maher et al. 2004). Palaeosol and root horizons associated with truncation surfaces at the top of barriersand packages suggest that some of the bars were emergent at times. The Dalkjegla Member represents the shallow marine portion of the first-order transgressive sequence that started with the Helvetiafjellet Formation (Gjelberg \& Steel 1995). Coarsening-upward packages on the order of 3-10-m thick within the Dalkjegla Member (e.g., Figs. 2, 3, 6) are often capped by sands with oscillation ripple marks and Diplocraterion traces, and are interpreted to represent higher-order regressive, shoaling packages. Other intermediate-order sequences are likely to be recognized, but are beyond the scope of this paper. 


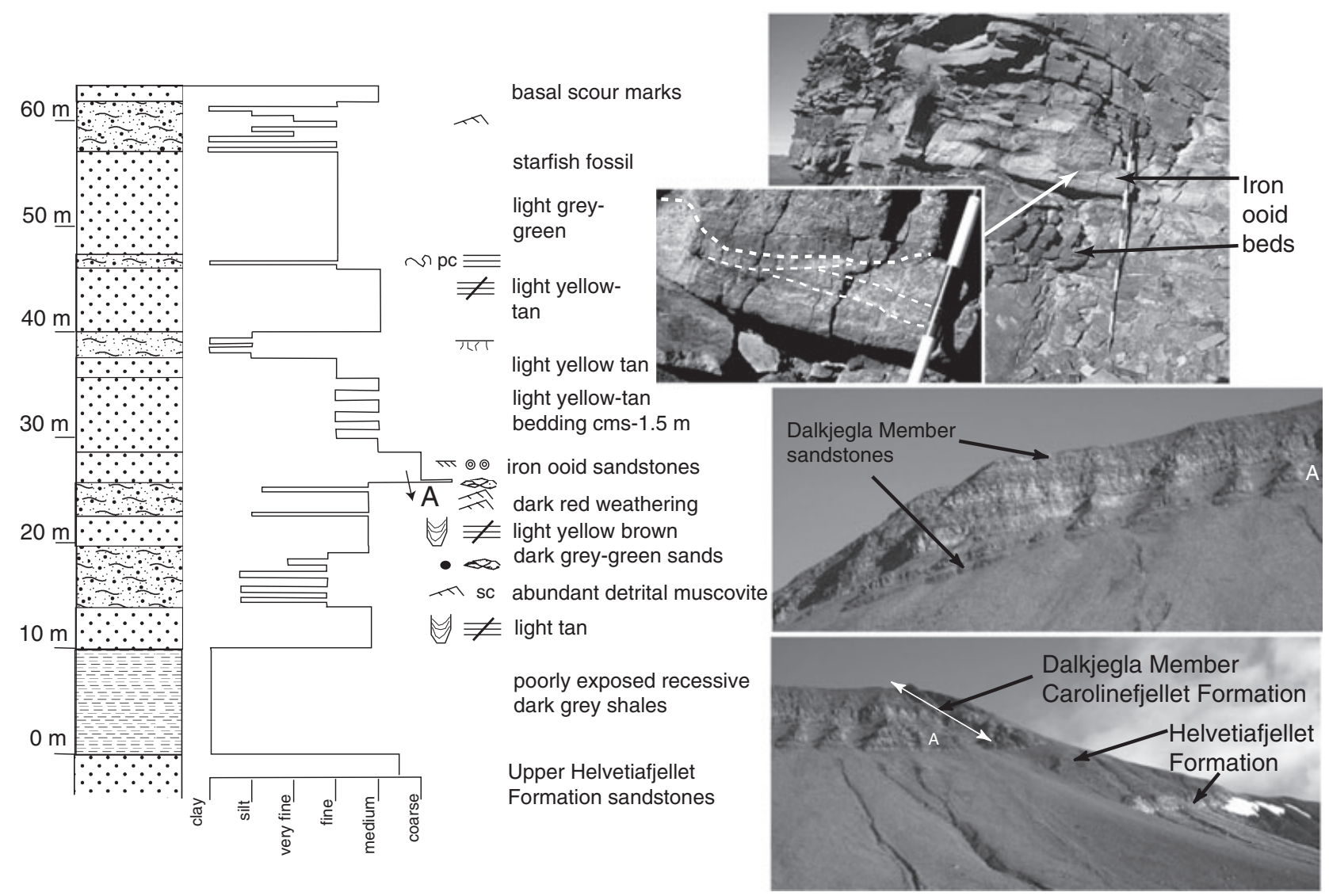

Fig. 4 Lithologic log showing the position of iron ooid beds along with field photographs from the Midterhuken site. Symbols are as indicated in the legend of Fig. 2. The bottom photograph is a view of the section site on Svedenborgstupet looking south. The middle photograph shows the cliff side of the Dalkjegla sandstones, with "A" marking the approximate position of the iron ooid horizon. The upper photograph shows the coarser speckled iron ooid sands, with an inset close-up photograph showing a siderite-filled trough above the heavy dashed white line, and the internal laminae in the coarse iron ooid sands below, highlighted by the thinner white dashed lines. The walking stick with 10-cm markings has been included for scale. Note the ripple forms indicating transport to the south.

Palaeogeographic reconstructions (e.g., Torsvik et al. 2002) show Svalbard at relatively high northern latitudes in Aptian times (ca. $60-70^{\circ} \mathrm{N}$ ). Glendonites found in the very upper part of the Dalkjegla Member, and throughout most of the overlying Innkjegla Member (Dallmann 1999; Maher et al. 2004) indicate cold bottom-water conditions, consistent with a polar setting (De Lurio \& Frakes 1999). Dypvik et al. (2002) indicate transgression continued in a punctuated manner into the Aptian. Shoreline retreat was generally to the north. The significant volcanic detritus that appears in the top section of the underlying Helvetiafjellet Formation, and continues throughout the Carolinefjellet Formation, is associated with the HALIP and with the surface volcanism that occurred to the north-east (Maher 2001; Maher et al. 2004).

\section{Sedimentology of the iron ooid beds}

In addition to containing the iron ooids, the iron ooid sandstone horizons are distinctive within the Dalkjegla Member in the following ways.

First, the sands are distinctly coarser grained (see lithologic logs in Figs. 2-6). The contrast between the white quartz grains and dark ooid grains produces a distinctive speckled appearance (photographs in Figs. 4-6). Dalkjegla Member sandstones are otherwise typically fine-grained (Wentworth 1922) sublitharenites and lithic arenites, often laminated and well sorted. Their relatively constant textural and compositional homogeneity throughout the Carolinefjellet Formation is attributed to thorough marine mixing in a storm-dominated platform environment (Maher et al. 2004). In contrast, the iron ooid 


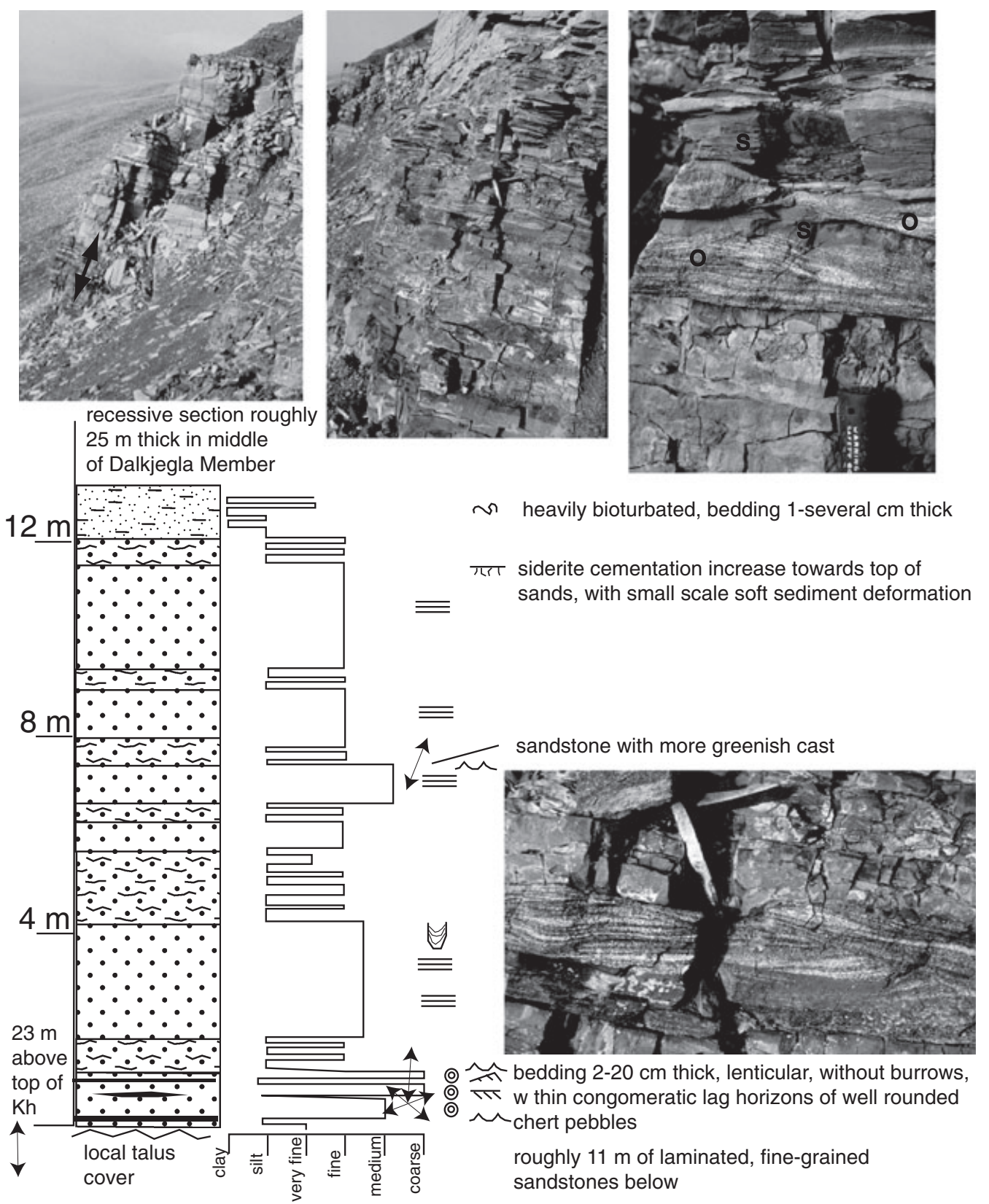

Fig. 5 Lithologic log of iron ooid beds along with field photographs from the site on the east side of Skolten. Symbols are as indicated in the legend of Fig. 2. Field photographs show successively closer images of the ooid horizon from left to right, and then down below. The middle photograph displays a hammer for scale. Note cross-bed and ripple forms in the coarser speckled sand horizons containing the dark ooid grains (0), mantled by finer grained siderite beds (S), in the upper right photograph and below. A high percentage of the dark grains are iron ooids.

horizons consistently have coarse- to very coarse-grained (Wentworth scale) sand, with occasional granules, and even locally, thin conglomeratic horizons. Individual beds are usually only 10-40-cm thick, but the iron ooid-bearing unit in aggregate can be up to 2 -m thick. At two locations, west Skolten and Festningen, petrified wood fragments (10-20-cm long) occur within the ooid-bearing sands.
Coarser grained, graded storm beds also occur at the very top of the Dalkjegla Member, and can contain rare iron ooid grains, but these beds are usually only tens of centimetres thick, and have their own distinctive compositional character (Maher \& Shuster 2007).

Second, at all five localities the upper portions of the stacked iron ooid horizons display high-angled cross-beds 


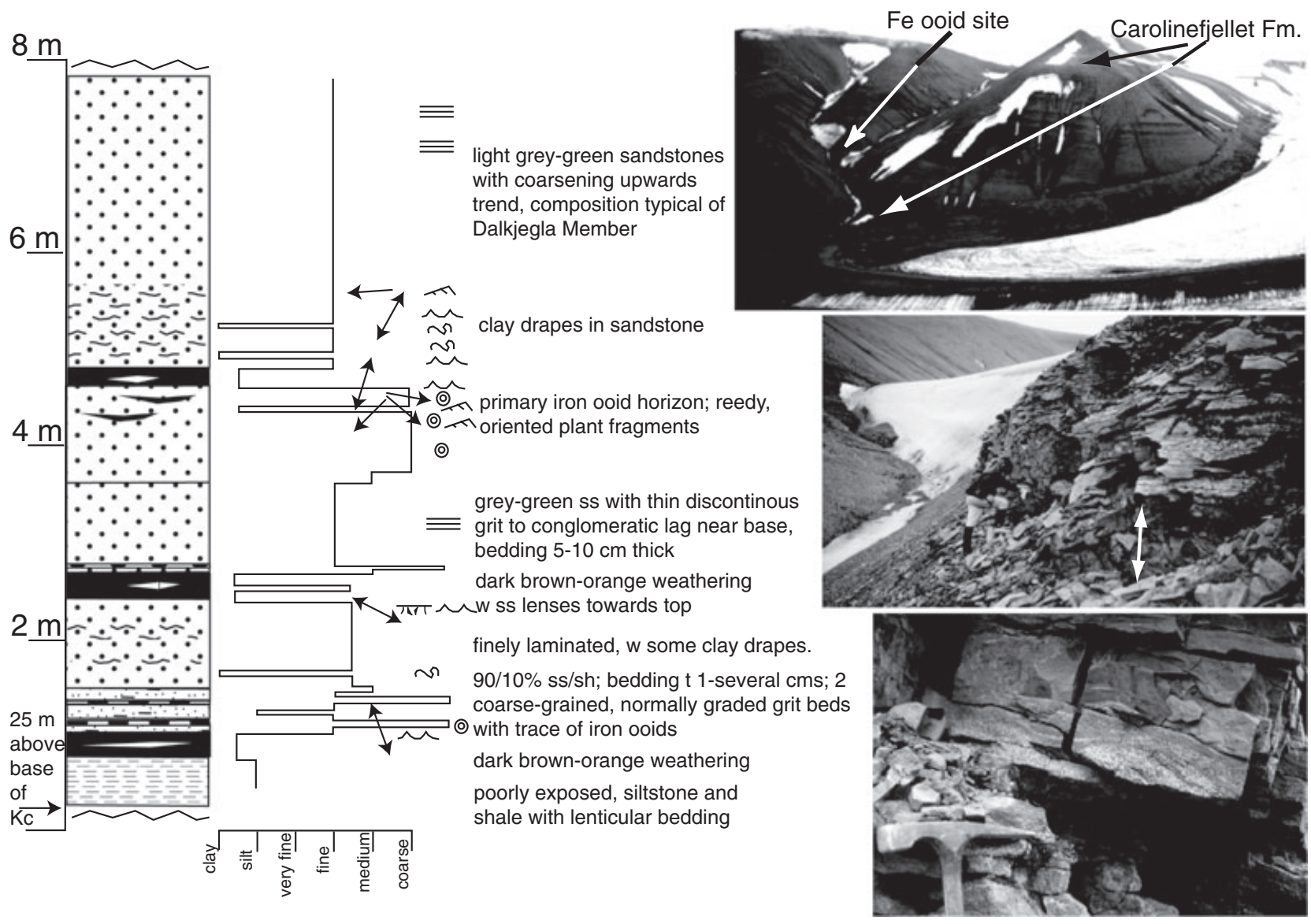

Fig. 6 Stratigraphic section of iron ooid horizon along with field photographs from the site on the west side of Skolten. Symbols are as indicated in the legend of Fig. 2. Field photographs show successively closer views of the iron ooid horizon from top to bottom. Note cross-bed forms with normal grading in speckled ooid horizons, and mantling by darker silty siderite layers, in the lower photograph.

and current-ripple forms (Figs. 2, 4, 5), which are otherwise relatively uncommon in the Dalkjegla Member sands. Associated sediment transport is consistently to the west and south, in the offshore and shore-parallel direction.

Third, there is a strong association of the ooid-bearing sands with silty siderite micrites (Figs. 2, 5, 6). The silty siderite micrites are typically orange-brown, as a result of weathering, massive in appearance and composed of $10-30 \%$ silt or fine-grained quartz. Such siderite material can overly, or be intimately intercalated with, the iron ooid sands. In places it mantles current-ripple forms in the ooid sands, or is concentrated as lenses in ripple troughs. Both the sands and the siderite-silt material show a lack of burrowing. Burrowing, however, is common throughout much of the finer grained units in the rest of the Carolinefjellet Formation (Maher et al. 2004). In thin section, the associated intercalated silty siderites at west Skolten are very rich in sand-sized lithics composed of fine-grained siderite with or without subsidiary iron sulfide. Many such clasts display peloidal, microlaminated, framboidal and other textures. Plant fragments are also common. Although appearing micritic in the field, these textures indicate that they were deposited as fine- to medium-grained sands and silts, and not as mud. Other siderite horizons have silt-sized quartz grains embedded in a microsparitic siderite matrix, and were likely to have been deposited as silts and muds.

Strata immediately above the iron ooid horizons are fine-grained sands, typical of the Carolinefjellet Formation, with planar lamination and oscillation ripple marks, and burrows. At Midterhuken similar sands occur immediately below the ooid horizons, whereas at the Festningen, Foxdalen and west Skolten sites similar sands below the ooid horizons have intercalations of muds and silts with abundant burrows (Figs. 2-6). There is not a marked difference in lithology or textures of sandstones above and below the iron ooid beds-they are embedded within similar sandstones of the lower part of the Dalkjegla Member (Maher et al. 2004), suggesting overall constancy of conditions during Dalkjegla time. 


\section{Textures, mineralogy and forms of ooids}

Thin-section analysis of a total of 12 ooid samples from the five study locations was performed. The ooid material is light-brown coloured in transmitted plain light, dark green in reflected light, has parallel extinction and low order birefringence with some anomalous colours, and exhibits hematite alteration in association with weathering surfaces. An X-ray diffraction (XRD) analysis (on a Miniflex instrument; Rigaku Americas, The Woodlands, TX, USA) of a hand-picked separate of ooidal material from the Festingen sample identified chamosite using standard computer match software based on peak location, intensity and the ICDD library. This identification is consistent with the optical characteristics of the minerals. The chlorite mineral family is very complex (Young $\delta$ Taylor 1989) and other phases may well be present. For the sake of simplicity, all minerals with the same general optical properties shall be referred to as chamosite herein, with the recognition that the mineralogy is likely to be much more complex and beyond the scope of this paper. In addition to chamosite, pyrite and siderite are common iron-rich phases that occur in the samples. The percentage of ooid clasts varies in individual sandstone layers from several to tens of percent, and most of these would be classified as lean iron ooid horizons $(<30 \%$; Bhattacharyya 1989).

A wide variety of nucleus materials, ooidal forms, mineralogy and degrees of deformation exist (Fig. 7). At Midterhuken and Festningen, the nuclei of the ooids are most commonly quartz grains. However, pyrite, carbonate lithics, chamosite aggregates and plagioclase also form ooid nuclei. At both Skolten sites, most of the nuclei are sulfides, chamosite material or carbonates. Many of these nuclei are finely laminated and have angular clast geometries, suggesting that they are broken-up hardgrounds or cementation surfaces (Fig. 7c, $\mathrm{d}, \mathrm{f}-\mathrm{h})$. Some chamosite aggregate nuclei show complex and various internal lamination patterns (e.g., colloform) that are truncated by the nucleus grain boundary. One such clast has internal laminations with low-angle truncations, undulations and micro-mound structures, along with high-angle tubular disruptions (Fig. 7f). Chamosite nucleus textures vary from peloidal (with framboidal pyrite) with no discernable structure, to coarser, randomly oriented fans of the chamosite, to laminated. In Fig. 7h a laminated chamositic intraclast is overprinted by partial alteration to coarser grained iron sulfide that is constrained to the nucleus, suggesting this alteration precedes the growth of grain-rimming chamosite laminae.

Ooids from all the sites typically display finer grained chamosite with a tangential orientation forming laminae on the inner part of the ooid, which can be classified as concentric ooids (Flügel 2004). Radial ooids are less common, but do occur (Fig. $7 \mathrm{~d}$ ). The presence of radial versus tangential chlorite in iron ooids has been attributed to growth/precipitation versus mechanical reworking (Young \& Taylor 1989). From several to several tens of laminae are typical. Laminae are typically less than $0.01 \mathrm{~mm}$ thick and are of relatively constant thickness in a radial transect (Fig. 7a, g). In many ooids the thickness of individual laminae remains constant (Fig. 7a), whereas in others, they thin and disappear, and can form micro-mound forms (Fig. 7b,c). There are also multiple occurrences of low-angle truncations between laminae within ooids (Fig. 7b). The laminae are defined by concentrations of small opaques and/or inclusions, and by variation in the coloration of the chamosite, with deeper brown hues associated with concentrations of opaques (Fig. 7c). Occasional cubic forms and reflected light indicate these opaques are iron sulfides. The proportion of small opaques can either decrease or increase from the interior outwards. Using the terminology of Flügel (2004) for describing the proportion of nucleus to cortex material, both superficial and normal ooids occur. The former commonly have siliciclastic nuclei, and the latter more typically have opague, siderite or chamosite nuclei. Most of the ooids are single ooids, but occasional compound grains exist (Fig. 7d).

Midterhuken and west Skolten samples also display alternating layers of chamosite and calcite in their

Fig. 7 Photomicrographs of iron ooids. Scale bars in the upper right corner are $0.1 \mathrm{~mm}$. (a) Iron ooid from Midterhuken; p, pyrite nucleus. (b) Iron ooid from Midterhuken; cc, calcite cement; on, opaque nucleus; s, siderite. Arrow shows mounded ooid laminae. Note internal laminae discordance in ooid. (c) Iron ooid from the east Skolten site with fossiliferous hardground nucleus (the white arrow points to the fossil fragment) and discontinuous alternating laminae of iron silicate and opaque material, and laminae truncation indicating post-depositional abrasion. (d) Iron ooid from east Skolten: clast with aggregate, intergrown ooids. Note opaque nuclei and non-circular sections in right portion of clast. V, predepositional calcite micro-vein. (e) Iron ooid from Midterhuken; o, ooid, ch, chert and q, quartz grains, with thin layer of chamosite cement with hemispherical growths (arrow) and a later calcite cement. (f) Iron ooid from Festningen. Laminated crust with possible burrow trace marked by arrows. Note that the clast is coated with a thin rind of ooid laminae. (g) Iron ooid from east Skolten with irregular nucleus of more massive chamosite material. The arrow points to where a small quartz grain has deformed the ooid margin. Note the discordance of internal laminae, and locations of laminae disruption. (h) Iron ooid from west Skolten. Large laminated chamosite grain with coarser growth of opaques constrained to grain interior. Upper right, more-massive grain of massive chamosite. The thin laminae of chamosite, shown by the white arrow, is partly detached, with calcite in the nucleus (black arrow) and as an outer layer. 

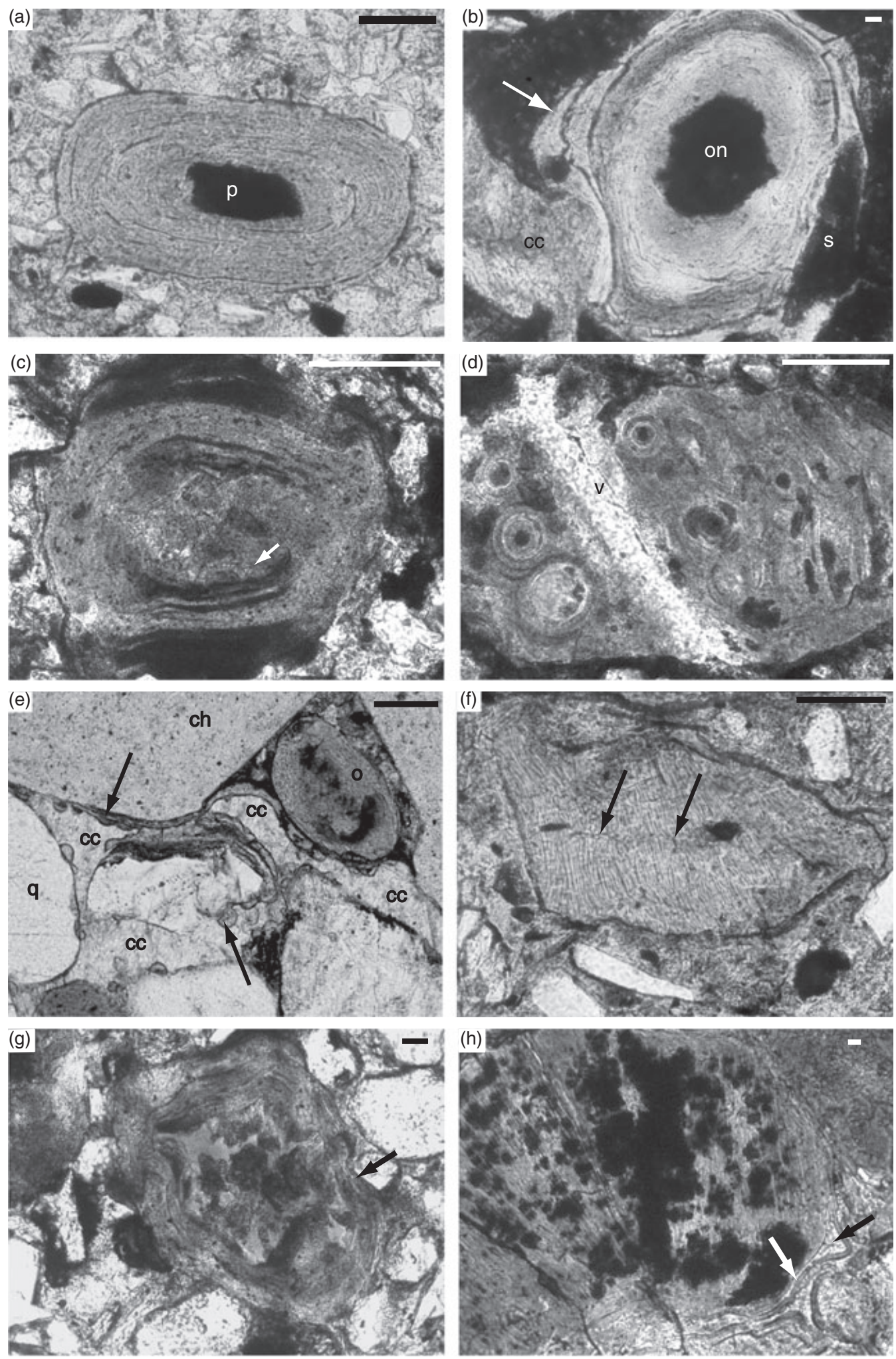
outermost layers (Fig. 7h). The congruent character of this calcite with respect to the ooid laminae and sharp, well-defined boundaries, distinguish it from a coarser phase of calcite that overprints and destroys the internal ooid grain structure. The congruent calcite is interpreted as primary. Iron sulfide replacement of ooid material also occurs in Foxdalen and Festningen samples, but is distinctive in its more massive, coarser grained and discordant, overprinting character.

Ooids have a great variety of shapes: both primary and those shaped by compaction-related deformation. Many undeformed ooids in the Dalkjegla Member have a spherical or flaxseed shape in thin section (Fig. 7a, e), but many irregular forms also exist. Figure $7 \mathrm{~g}$ shows laminae subcordant to an irregular intraclast nucleus. In this case, the curvature of the laminae irregularities mainly decreases outwards, a geometry that is inconsistent with compaction-related deformation. Some compactionrelated deformation can be seen on the right side of the grain. Figure 7d also shows a clast of intergrown ooids, some with circular and some with distinctly non-circular cross-sections. Some of these shapes resemble oncoids, but the clasts are composed of chamosite and not carbonate material.

Many of the ooids found from all three localities have been deformed in some way, and can be considered as spastoliths (Young \& Taylor 1989). Ooids from the Skolten site with the pyrite-chamosite nuclei are the most deformed. The long to short axis ratio is as great as $7: 1$, and the flattening plane can be bent around adjacent more-rigid grains. In these grains, laminae thickness is not constant, but changes in a manner consistent with post-depositional deformation. Small microfaults of the laminae can also be seen. Adjacent quartz grains often serve as rigid indentors, squeezing the chamosite between them. Where present, poikilitic calcite cement (discussed below) preceded or overlapped in time with this deformation, protecting other grains from later compactionrelated deformation.

Grain types accompanying the ooids in decreasing order of abundance include well-rounded unstrained quartz, chert lithics, fine-grained siderite and opaque lithics, metamorphic lithics, volcanic lithics, and plagioclase feldspar. The sandstones range mainly from sublithic arenites to lithic arenites. Disregarding the iron ooids, this assemblage is broadly typical of the Carolinefjellet Formation sandstones (Maher et al. 2004), but with a greater proportion of fine-grained siderite-opaque lithics.

\section{Cementation and diagenesis}

Carolinefjellet Formation strata have suffered significant diagenesis and cementation, which varies significantly over short stratigraphic distances (Maher et al. 2004). Present porosities are typically of several percent or less. A poikilotopic coarse calcite cement is common over stratigraphic intervals of several metres within the typical finegrained Carolinefjellet Formation sands, and where present, original grain shape is also well preserved. Ooids enclosed in this cement can still be notably deformed. Where this carbonate cement is absent, grain moulding and pressure solution of quartz grains is notable, the cement percentage is reduced by $15-20 \%$, and quartz overgrowths and clay fills dominate (Maher et al. 2004).

At Midterhuken, Festningen and Skolten the iron ooids have coarser grained, radially oriented, isopachous chamosite as an early drusy cement, which coats the outer part of many of the ooids as well as non-ooidal grains. In Midterhuken samples, small mounds occur in this early rimming cement (Fig. 7e). The isopachous chamosite is followed by either the poikilitopic calcite cement (Fig. 7e), or by other phases of more massive or bladed chamosite fill and associated pyrite.

Later calcite replacement of some chamosite ooids is evident as an equigranular spar that overprints ooid and early cement textures, leaving remnants of the original 'rind' of the chamosite ooid. Small calcite veins, which are likely to have been a very late development, cross-cut ooids as well as the calcite spar. Some samples also contain traces of a reddish mineral (in plain light), which is interpreted to be hematite. This is inferred to be a late oxidation, and is associated with weathered surfaces.

Foxdalen samples show localized, but severe, replacement by pyrite. Similar pyritization is also associated with a storm bed at the top of the Dalkjegla Member (Maher $\&$ Shuster 2007), and with the Jurassic Brentskardhaugen storm bed (Maher 1989). In this sample associated ooids are only partially preserved, and are now composed of siderite and not iron silicate, and carbonate clasts occur in greater abundance. Micro seams of pyrite locally truncate quartz and other grains, suggesting significant local dissolution.

More typically, fine-grained and delicate ooid and laminae structures, defined by chamosite, pyrite, siderite and calcite, are well preserved on a thin section scale. Cementation and authigenesis also vary on a scale of metres or less (Maher et al. 2004). A common and pervasive diagenetic overprint is not evident in these strata. Instead, the diagenetic effects can be characterized by their complexity and variation on a thin section to outcrop scale.

\section{Discussion}

Figure 8 is a depiction of our model for the genesis of the iron ooid horizons that builds on existing depositional 


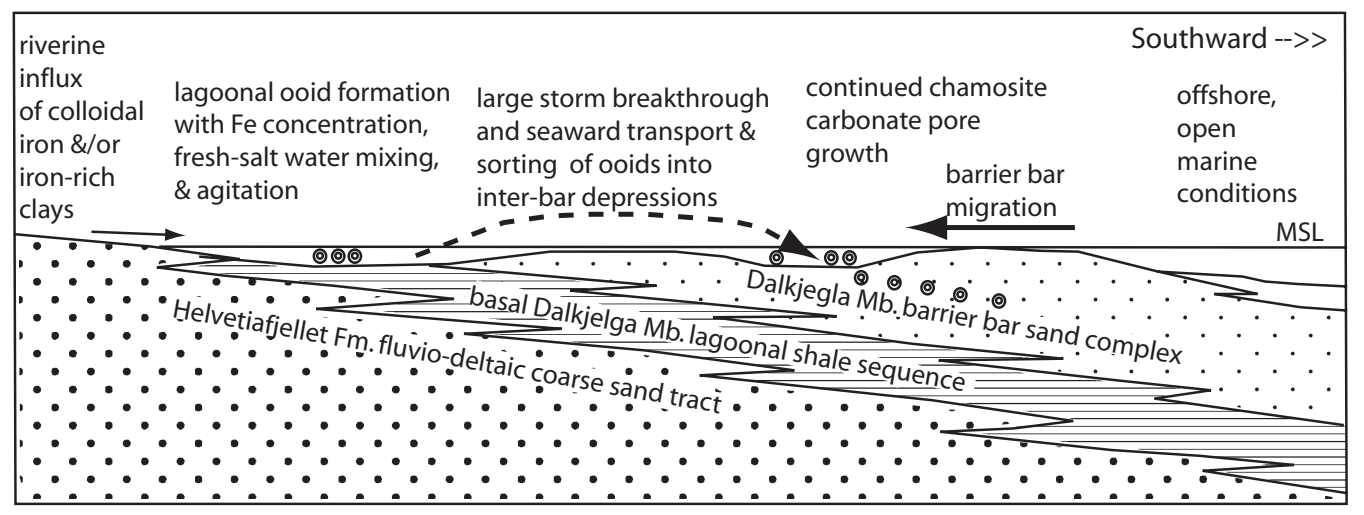

Fig. 8 Model for iron ooid formation, transport and preservation.

models for the Helvetiafjellet and Carolinefjellet formations, and on the observations noted above. As described by Gjelberg \& Steel (1995), Dypvik et al. (2002) and Maher et al. (2004), the depositional settings for the Helvetiafjellet Formation and the Dalkjegla Member of the Carolinefjellet Formation were that of a first-order transgresssive sand system, with coarser grained fluvial and estuarine sands separated from barrier-bar sand bodies by a lagoonal environment. Further south and offshore were open marine, shallow-shelf conditions. In this model we propose that a riverine supply of iron clays and/or colloids, restricted conditions, and mixing of fresh and salt water within the lagoon, along with tidal and/or shallow-wave agitation, provided a setting for iron ooid formation. Larger storms mixed coarser estuarine sands with lagoonal sediments, and transported them into swale positions between barrier-bar complexes. Quick storm-related burial allowed for the preservation of the iron ooids. Subsequent transgression-related migration sandwiched the iron ooid horizons between the finegrained bar sands of the Dalkjegla Member. The following discusses evidence and a more detailed rationale for the model. The depositional setting is considered first, followed by the setting of the ooid formation. Finally, the global context for the Cretaceous iron ooids of Spitsbergen is briefly explored.

\section{Iron ooid transport and deposition}

Their different characters suggest different sediment sources for the iron ooid beds and for the enclosing Dalkjegla fine-grained sands. Additionally, as described below, iron ooid formation is incompatible with the oxygenated water conditions (Taylor et al. 2002) that can be inferred from the oscillation ripple marks and burrowing seen in the enclosing Dalkjegla Member sands. So, different environments, one for ooid formation and one for ooid preservation, with transport from the former to the latter, must be considered. Lean ooid deposits, such as those discussed here, are typically associated with transportation from the initial site of formation (Bhattacharyya 1989). The intimate intercalation of, and grading between, the ooid sands and silty siderite mud (Figs. 5, 6), and the unburrowed character of the sediment, indicate that both lithologies were deposited as part of the same event. The enclosing Dalkjegla Member laminated sands are associated with wave and storm reworking of barrier-bar sands, on a wave/tideinfluenced shallow shelf (Nøttvedt \& Kriesa 1987; Dallmann 1999; Dypvik et al. 2002; Maher et al. 2004), and in this context it is reasonable to consider the role that storms may have played in the transport and preservation of the ooid material.

Larger storms could produce the necessary seaward transport in two ways. Large flood-associated, sedimentladen, freshwater excursions could transport fluvioestuarine and lagoonal sediment into depressions in the barrier-bar complex. Alternatively, for low-relief barrierbars that could be flooded during a larger storm surge, bottom-hugging traction currents driven by seawarddirected, surge-related, return flow (Walker 1984) could be invoked. The latter produces distinctive, coarsegrained and normally-graded storm beds (e.g., Maher 1989). An upper, fine-grained laminated storm bed portion is associated with waning storm conditions and currents, wave reworking, and settling of suspended material.

The seaward to longshore transport directions, distinctly coarser grain size (Figs. 2-6), and larger wood fragments associated with the iron ooids are all consistent with seaward storm transport. Additionally, more vigorous storm transport could tap into more distal sediment sources not typically represented in the Dalkjegla Member sandstones. Tidal channel transport could also 
bypass interior bars, but would not explain the other distinctive traits associated with the iron ooid horizon, such as the close association with fine-grained micrites. The iron ooid beds with cross-stratification are consistent with flood-related freshwater excursion transport as the dominant mechanism. The normally graded pyritized iron ooid beds, such as those seen at Foxdalen, could reflect a local storm surge-related transport mechanism that flooded low-relief barrier bars. Quickly buried organics in a storm bed leads to anoxic conditions, which promotes bacterial sulfate reduction and sulfide authigenesis.

With a seaward transport direction, temporal equivalents of the underlying fluvio-estuarine Helvetiafjellet Formation, which contains abundant well-rounded coarse-grained sand, would provide a source to the north and north-west (Fig. 8). The intervening lagoonal environment would provide the appropriate chemical environment for ooid growth (see discussion below). As the iron ooids are stratigraphically sandwiched in between offshore bar sands (Figs 2-6), a simple application of Walther's law would suggest that bar sands existed on either side of their final resting place (Fig. 8). During larger storm events the inter-bar swales would be sites of slightly deeper water and enhanced storm-bed deposition. Burial in such a position would help protect the sediment from subsequent reworking, allowing preservations of the ooids transported during the storm event. The greater proportion of finer grained thinner bedded strata seen below the ooid unit at Festningen, Foxdalen and west Skolten are consistent with an interbar setting. Subsequent longshore drift and sand-bar migration (Maher et al. 2004) would preserve the iron ooid horizons within the Dalkjegla Member sands.

\section{Conditions and setting of iron ooid formation}

Figure 8 implies that iron ooids might be expected in the muddy lagoonal strata at the very base of the Carolinefjellet Formation. However, they have not yet been found in outcrops of the shaley sediments below the Dalkjegla Member sands and above the Helvetiafjellet Formation sands. Several factors could explain their absence. The shales outcrop poorly, and more careful and extensive searching may be needed to find examples of preserved iron ooid 'factories'. Bioturbation, compaction and shale diagenesis would also obscure or destroy the ooids, and therefore their recognition in the field may be difficult. Given their sensitivity to chemical conditions, quick burial may be required for preservation: i.e. the long-term preservation potential in a lagoonal environment may be low. Therefore, we use the observed mineralogy and internal textures of the ooids, the stratigraphic and palaeogeo- graphic setting, and the literature to constrain both the conditions and setting of the formation.

Iron silicate iron ooids are typically composed of chamosite or bethierine, with chamosite ooids, such as those described here, thought to be a thermal diagenetic product of berthierine (Young \& Taylor 1989). Berthierine formation requires anoxic conditions with low or no sulfide activity (otherwise iron sulfides form), and a source of iron and aluminum. Two sources of the iron and aluminum are precursor clays or colloidal transport (Young \& Taylor 1989). Several challenges exist in explaining formation of iron silicate ooids in the shallow marine settings in which they are often found. First, the bacterial reduction of marine sulfates general favours iron sulfide formation. Framboidal pyrite is very common in the Carolinefjellet Formation. Another difficulty is that oxygenated bottom-water conditions are often associated with the strata that iron ooids are found within, but such oxic conditions are inconsistent with iron silicate formation (Taylor et al. 2002). Finally, modern ocean waters are relatively poor in iron (Poulton \& Raiswell 2002).

Taylor et al. (2002) explore a model for berthierine iron ooid formation for two Albian iron ooid horizons in the Western Interior Seaway of the North American continent. The difficulty of reconciling evidence for oxygenated water conditions with the requirement of anoxic conditions for iron silicate growth is addressed by bertheriene replacement of accreted ooid clays and oxides, during shallow-burial suboxic diagenesis, with subsequent excavation by storm processes. The ooids cycle through a process of accretion and shallow-burial diagenesis multiple times. One of the two horizons they describe formed in an estuarine setting, where reduction of sulfide activity by freshwater-saltwater mixing would also favour iron silicate formation. The other horizon formed in a more offshore position, where they propose low sedimentation accumulation rates and extended reworking in an open marine environment produced sediment low in organic matter and high in iron oxide. Without organics driving bacterial reduction of sulfate, bacterial iron reduction can take place and authigenic berthierine replacement could occur.

The Spitsbergen iron ooids also show evidence of multiple cycles of growth, with broken grains as nuclei. This diversity of nucleus material suggests that the nucleus material provided a physical foundation for ooid growth, and did not play a critical chemical or 'seed' role. However, the fine-grained nuclei can give insight into the conditions of ooid formation. Laminated and massive chamosite nuclei indicate that the original formation of the iron clays or bertheriene occurred in multiple forms (not just as grain coatings). The common iron sulfide nucleus of many of the ooids is consistent with initial 
anoxic waters with a marine component. A change to waters of low sulfide activity (suboxic conditions) would favour iron silicate precipitation and/or replacement. The concordant and alternating character of the laminae of fine-grained iron sulfide within chamosite (Fig. 7c) is consistent with a primary origin. This suggests continued fluctuation of the water sulfide activity during ooid growth. The alteration of a laminated chamosite intraclast nucleus to coarser pyrite, preceding ooid laminae growth (Fig. 7h), also indicates fluctuating chemical conditions with respect to iron mineral growth. The observed precipitation of the iron silicate phase as an isopachous pore cement with a radial texture, seen in the Dalkjegla Member, also indicates formation by precipitation from a solution, a relationship and a conclusion associated with other ooid horizons (Young \& Taylor 1989).

Poikilotopic calcite spar cement, such as that seen in association with the Midterhuken ooids, is commonly (although not always) associated with an influx of meteoric water (e.g., Leeder 1982; Raymond 2002; Stone \& Siever 1996). Such poikiloptopic calcite cements exist intermittently within the Carolinefjellet Formation sands (Maher et al. 2004), and are a pre-compaction, early cement phase that overlaps in time with iron silicate pore cementation (Fig. 7e, h). Freshwater aquifers associated with emergent barrier-bar complexes (Maher et al. 2004) could provide the required meteoric input. Associated porewaters would also have low sulfide activity, allowing both the preservation of the ooids and the development of the iron silicate isopachous pore cement.

Biologic mediation has been invoked as an important part of ironstone and ooid development (e.g., Konhauser et al. 2002; Petránek \& Van Houten 1997; Taylor et al. 2002). Tubular disruptions of laminated chamositic ooid nuclei may represent microborings (Fig. 7f, h), possibly by endolithic algae, and, more speculatively, mounded forms of iron silicate laminae (Fig. 7b) may reflect microbial activity and the development of algal mats. Sticky biofilms could aid tangential clay accretion. Many of the nuclei also have concordant ooid laminae in geometries that are inconsistent with accretion caused by mechanical rolling (e.g., Fig. 7g). If these are biocoatings, then these grains would be similar to oncolites but with an iron silicate instead of calcareous composition.

Additionally, the model of Taylor et al. (2002) does not explain why clay oolites always experience burial under suboxic conditions, and why untransformed or differently transformed clay oolites are not more commonly preserved. An alternative is that the required suboxic conditions are not produced by burial, but by a microchemical environment of a biocoating. Thus, the biocoating provides both the mechanism for ooid development and for chlorite growth, and the two could be inextricably linked. Such biocoatings could also explain the relatively constant laminae thickness. A lagoonal environment provides sheltered conditions for the development of algal mats and coatings.

A setting of iron ooid formation needs to provide the appropriate conditions and a source of iron. Possible iron sources cited for iron ooid formation are: (a) weathering products of lateritic soils (Prothero \& Schwab 1996: 303; Taylor 1996); (b) marine volcanic exhalatives (Young $\&$ Taylor 1989; Heikoop et al. 1996; Taylor 1996; Sturesson 2003) or seeps related to tectonic faults (Collom 2001); (c) iron concentration in sediment-starved marine conditions (Taylor et al. 2002); or (d) flocculation of colloidal riverine iron in a saltwater-freshwater mixing environment (Yan et al. 1991; Schieber 1995). The estuarine character of the Helvetiafjellet Formation has been noted (Gjelberg \& Steel 1995). Spitsbergen's High Latitude would not have been conducive to laterite development. Glendonites in the Carolinefjellet Formation (Dallmann 1999; Maher et al. 2004) indicate cold water conditions for at least the upper part of the Dalkjegla Member. In addition, the preservation of plagioclase feldspar in the associated Dalkjegla Member sands (Maher et al. 2004) is inconsistent with significant laterite development. However, the penecontemporaneous development of the HALIP (Maher 2001) may have contributed to iron ooid formation via the weathering of associated mafic volcanics that existed to the east, and an increase in the flux of riverine iron. No evidence for seeps or active tectonic faults during Dalkjegla Member deposition exists to our knowledge.

Many iron ooid horizons are associated with major transgressions that produce sediment-starved shelves, with extensive reworking by storm events (Young $\delta$ Taylor 1989; Garzanti 1993; Taylor et al. 2002). Sediment starvation and reworking produces a low organic content and a high iron content, and thus favourable iron ooid formation conditions. Reworking of soils that developed before the transgression could play a role in providing iron. Such iron ooid horizons are often within shaledominated sections that lie above a sequence boundary. Although the Dalkjegla iron ooid horizons occur within a transgressive sequence (Gjelberg \& Steel 1995; Dypvik et al. 2002), they are also embedded within the sandstone-dominated Dalkjegla Member, and are clearly not associated with a flooding surface above a sequence boundary. The intervening fluvio-estuarine Helvetiafjellet Formation precludes such a possibility. Although portions of the Carolinefjellet Formation, such as the overlying Innkjegla Member, were formed in deeper water during sediment-starved conditions, during the deposition of the shallow-water Dalkjegla Member sands, deposition kept pace with subsidence for a 60-100-m 
stratigraphic interval, a behaviour that is inconsistent with general sediment starvation.

Of the depositional environments represented in the Helvetiafjellet Formation and Dalkjegla Member transgressive sediments, a lagoonal environment with an estuarine mixing of fresh and saltwater, and associated flocculation of colloidal iron, provides optimal conditions for ooid formation. Modern studies indicate that most colloidal riverine iron is flocculated, and concentrates in estuaries and nearshore environments (Yan et al. 1991; Poulton \& Raiswell 2002). A lagoonal setting would provide the locally protected and suboxic substrate conditions favourable for iron silicate ooid formation. The introduction of fresh or brackish water in such a setting could also help to locally suppress sulfate and or sulfide production (Taylor et al. 2002), thereby promoting the conditions for chlorite and siderite growth. Opportunities for shallow-water agitation or biofilm formation would abound. Shifting tidal channels and deltaic lobes could produce multiple cycles of burial and excavation, and for swiftly changing hydraulic and porewater regimes. This would be consistent with the observed complex petrogenesis and distribution of iron sulfide, tangential and radial iron silicate laminae, siderite and calcite seen in the ooids and early cements, and diagenetic products.

\section{Global context}

Ironstones are more prevalent during two major periods during the Phanerozoic: one lasting from the Ordovician until the Devonian, and one lasting from the Jurassic until the Neogene, with peaks during the Ordovician and the Jurassic (Van Houten \& Arthur 1989). These periods also coincide with theorized superplume activity characterized by increased oceanic spreading rates and volcanism, and Garzanti (1993) argued that superplume activity drove transgressions, thereby drowning shelves and producing conditions conducive to ironstone formation. This timing also links ooids to major periods of black shale deposition (Van Houten \& Arthur 1989). The Dalkjegla Member ooid horizon does roughly coincide in time with the development of the HALIP (Maher 2001), but a direct connection cannot be established at this time. An increase in coastal iron supply resulting from basalt extrusion and weathering seems the simplest link.

Globally, iron ooids have been associated with lateritic soil formation in lower latitudes (Young \& Taylor 1989), and the vast majority were deposited $45^{\circ}$ either side of the equator. High-Latitude exceptions include the Devonian deposits of Belgium, which have been linked to volcanism, and the Ordovician deposits of Europe, the iron source of which is unknown (Van Houten \& Arthur
1989). The Spitsbergen deposits formed in one of the more northern palaeopositions known to date $\left(\mathrm{ca} .70^{\circ} \mathrm{N}\right.$; Torsvik et al. 2002), and reinforce a conclusion that the commonality between all iron ooids has yet to be developed.

\section{Conclusions}

Chamosite ooid beds occur consistently about 22-30 m above the base of the Dalkjegla Member, over a wide area, and represent an important, distinctive and previously unrecognized regional stratigraphic horizon in central Spitsbergen.

The iron ooids are part of a distinctive sedimentary association in the basal Daljegla Member of the Carolinefjellet Formation, defined by coarser grain sands, larger high-angle cross-beds, silty siderite muds and a lack of burrowing, and by the iron ooids themselves.

An iron ooid depositional setting of swales within a barrier-bar complex on an otherwise wave- and stormdominated shelf, with seaward storm-related transport, best explains the associated features and the stratigraphic setting.

Textures and mineralogy of the ooids and cements indicate fluctuating and evolving water conditions, from anoxic with sulfide growth, to suboxic with iron silicate growth, to freshwater sparry cements. Ooid growth involved multiple episodes of growth and reworking.

Of the environments preserved in the transgressive sequence, a lagoonal setting between the fluvio-estuarine sands represented by the Helvetiafjellet Formation, and the barrier bars represented by the Dalkjegla Member sands (within the Carolinefjellet Formation), provides optimal conditions for iron ooid formation.

The high-latitude palaeoposition of these iron ooids suggests laterites were not the source of the iron-rich fluids, as has been proposed for other iron ooid horizons.

The Dalkjegla iron ooids are within a transgressive sequence, but are not directly related to transgressive flooding of a shelf and the associated sediment starvation, as are many other iron ooid horizons.

In this case, the most likely connection between magmatic events and iron ooid horizons, as proposed by Garzanti (1993), may be an increased supply of iron- and aluminum-rich clays and colloids caused by greater exposure of mafic rocks, coupled with a selective lagoonal/ estuarine trapping, and storm-bed preservation.

\section{Acknowledgements}

Financial support was provided by grants from the Petroleum Research Fund and the University of Nebraska. The Norwegian Polar Institute is gratefully acknowledged for 
its help with logistics. Ron Steel, Kevin Taylor, Knut Bjørlykke and Dierk Blomeier are thanked for their careful review comments, which helped to substantially improve this paper; however, any errors are our own.

\section{References}

Bhattacharyya D.P. 1989. Concentrated and lean oolites: examples from Nubia Formation at Aswan Eygpt, and significance of the oolite types in ironstone genesis. In T.P. Young \& W.E.G. Taylor (eds.): Phanerozoic ironstones: an introduction and review. Pp. 93-103. London: Geological Society of London.

Birkenmajer K. 1966. Lower Cretaceous tidal deposits of central Vestspitsbergen. Norsk Polarinstitutt Årbok 1964, 73-85.

Collin P.Y., Loreau J.P. \& Courville P. 2005. Depositional environments and iron ooid formation in condensed sections (Callovian-Oxfordian, south-eastern Paris basin, France). Sedimentology 52, 969-985.

Collom C.J. 2001. Ooidal ironstones: products of exhalative paleoenvironments in shallow epeiric seas. Poster presented at Earth System Processes-Global Meeting. 24-28 June, Edinburgh, UK.

Dallmann W. 1999. Lithostratigrapic lexicon of Svalbard. Tromsø, Norway: Norwegian Polar Institute.

De Lurio J. \& Frakes L.A. 1999. Glendonites as a paleoenvironmental tool: implications for early Cretaceous High Latitude climates in Australia. Geochimica et Cosmochimica Acta 63, 1039-1048.

Dypvik H., Håkonsson E. \& Heinberg C. 2002. Jurassic and Cretaceous palaeogeography and stratigraphic comparison in the North Greenland-Svalbard region. Polar Research 21, 91-108.

Flügel E. 2004. Microfacies of carbonate rocks. Berlin: Springer.

Garzanti E. 1993. Himalayan ironstones, "superplumes," and the breakup of Gondwana. Geology 21, 105-108.

Gjelberg J. \& Steel R.J. 1995. Helvetiafjellet Formation (Barremian-Aptian) Spitsbergen: characteristics of transgressive succession. In R.J. Steel et al. (eds.): Sequence stratigraphy on the northwest European margin. Pp. 571-593. Amsterdam: Elsevier.

Heikoop J.M., Tsujita C.J., Risk M., Tomascik T. \& Mah A. 1996. Modern iron ooids from a shallow-marine volcanic setting: Mahentang, Indonesia. Geology 24, 759-762.

Konhauser K.O., Hamade T., Raiswell R. Morris R., Ferris F.G., Southam G., Canfield D.E. 2002. Could bacteria have formed the Precambrian banded iron formations? Geology 30, 1079-1082.

Leeder M.R. 1982. Sedimentology, process and product. London: George Allen \& Unwin.

Maher H.D., Jr. 1989. A storm related origin for the Jurassic Brentskardhaugen Bed, Spitsbergen. Polar Research 7, 67-77.

Maher H.D., Jr. 2001. Manifestations of the Cretaceous High Arctic Large Igneous Province in Svalbard. Journal of Geology 109, 91-104.
Maher H.D., Jr., Hays T., Shuster R.D. \& Mutrux J. 2004. Petrography of Lower Cretaceous sandstones on Spitsbergen. Polar Research 23, 142-165.

Maher H.D., Jr. \& Shuster R.D. 2007. Attributes of a Cretaceous storm bed from Spitsbergen, Norway. Poster presented at the 4lst Annual Meeting of the South-Central and North-Central Sections, Geological Society of America. 11-13 April, Lawrence, KS, USA.

McCubbin D.G. 1982. Barrier-island and strand-plain facies. In P.A. Scholle \& D. Spearing (eds.): Sandstone depositional environments. AAPG Memoir 31. Pp. 247-279. Tulsa, OK: American Association of Petroleum Geologists.

Nøttvedt A. \& Kriesa R.D. 1987. Model for the combined-flow origin of hummocky cross-stratification. Geology 15, 357-361.

Petránek J. \& Van Houten F. B. 1997. Phanerozoic ooidal ironstones. Prague: Czech Geological Survey.

Poulton S.W. \& Raiswell R. 2002. The low-temperature geochemical cycling of iron: from continental fluxes to marine sediment deposition. American Journal of Science 302, 774-805.

Prothero D.R. \& Schwab F. 1996. Sedimentary geology. 2nd edn. New York: W.H. Freeman and Company.

Raymond L.A. 2002. Petrology: the study of igneous, sedimentary and metamorphic rocks. 2nd edn. New York: McGraw-Hill.

Schieber J. 1995. Anomalous iron distribution in shales as a manifestation of "non-clastic iron" supply to sedimentary basins: relevance for pyritic shales, base metal mineralization, and oolitic iron deposits. Mineralium Deposita 30, 294-302.

Stone W.N. \& Siever R. 1996. Quantifying compaction, pressure solution and quartz cementation in moderately and deeply-buried quartzose sandstones from the Green River Basin, Wyoming. In L.J. Crossey et al. (eds.): Siliciclastic diagenesis and fluid flow. Pp. 129-150. Tulsa,: Society for Sedimentary Geology.

Sturesson U. 2003. Lower Paleozoic iron oolites and volcanism from a Baltoscandian perspective. Sedimentary Geology 159, 241-256.

Tarduno J.A. 1998. The High Arctic Large Igneous Province. Paper presented at the Third International Conference on Arctic Margins. 12-16 October, Celle, Germany.

Taylor K.G. 1996. Early Cretaceous iron ooids in the Paris Basin: pedogenic vs marine origin and their palaeoclimatic significance. Cretaceous Research 17, 109-118.

Taylor K.G., Simo A., Yocum D. \& Leckie D. 2002. Stratigraphic significance of ooidal ironstones from the Cretaceous. Journal of Sedimentary Research 72, 345-356.

Torsvik T.H., Carlos D., Mosar J., Cocks R.M. \& Malme T.N. 2002. Global reconstructions and North Atlantic paleogeography 440 Ma to recent. In E.A. Eide (ed.): BATLAS-Mid Norway plate reconstruction atlas with global and Atlantic perspectives. Pp. 18-39. Trondheim: Geological Survey of Norway. 
Van Houten F.B. \& Arthur M.A. 1989. Temporal patterns among Phanerozoic oolitic ironstones and oceanic anoxia. In T.P. Young $\&$ W.E.G. Taylor (eds.): Phanerozoic ironstones: an introduction and review. Pp. 33-49. London: Geological Society of London.

Walker R.G. 1984. Shelf and shallow marine sands.

In R.G. Walker (ed.): Facies models. 2nd edn. Pp. 141-170. St. Johns, NL: Geological Association of Canada.

Wentworth C.K. 1922. A scale of grade and class terms for clastic sediments. Journal of Geology 27, 507-521.
Yan L., Stalard R.F., Key R.M. \& Crear D.A. 1991. Trace metals and dissolved organic carbon in estuaries and offshore waters of New Jersey, USA. Geochimica et Cosmochemica Acta 55, 3647-3656.

Young T.P. \& Taylor W.E.G. 1989. Phanerozoic ironstones: an introduction and review. In T.P. Young $\delta$ W.E.G. Taylor (eds.): Phanerozoic ironstones: an introduction and review. Pp. ix-xxv. London: Geological Society of London. 